EUROPEAN UNIVERSITY INSTITUTE, FLORENCE

DEPARTMENT OF LAW

EUI Working Paper LAW No. 2004/1

EU Employment Policy:

Decentralisation or Centralisation through

the Open Method of Coordination?

STIJN SMISMANS

BADIA FIESOLANA, SAN DOMENICO (FI) 
All rights reserved.

No part of this paper may be reproduced in any form without permission of the author(s)

(C) 2004 Stijn Smismans

Published in Italy in February 2004

European University Institute

Badia Fiesolana

I - 50016 San Domenico (FI)

Italy 


\title{
EU Employment Policy: Decentralisation or Centralisation through the Open Method of Coordination?
}

\author{
Stijn Smismans*
}

\section{Introduction}

The Open Method of Coordination (OMC) is a "new mode of governance' ${ }^{1}$ that has (formally) been introduced by the Lisbon European Council of March 2000. This new mode of EU governance should incite the attention of regional and local actors since one of its key features is its assumed 'decentralised approach'. Before being baptised as 'OMC' and applied in policy sectors as social inclusion, education policy, and pension reform, this mode of governance had already been introduced in the sector of European employment policy, which, therefore, could be considered 'the mother of OMC'.

This paper will focus on European employment policy as described in the Employment Title of the EC Treaty; i.e. it looks at the OMC or guidelines procedure aiming at the coordination of national employment policies, and thus not at the role of European legislation based on the EC Treaty's social policy provisions ${ }^{2}$ nor at other policies that may affect growth and job-creation in the EU such as monetary, fiscal, and wage policy. ${ }^{3}$ The analysis starts with a brief description of the guidelines procedure, describing the reasons of emergence and features of this new mode of governance and identifying common characteristics and differences with OMC procedures in other policy fields (section 2). This paper will subsequently take into consideration the assumed decentralised approach of the OMC; neither the OMC's peer review process nor the implementation of the Employment guidelines are as decentralised as the institutional rhetoric suggests (section 3). The OMC could rather be dubbed an 'Open Method of Centralisation'; 'centralisation' since it leads to the definition at the central

I would like to thank Caroline de la Porte for her very useful comments on an earlier draft of this paper. The usual disclaimer applies.

J. Scott and D.M. Trubek, Mind the Gap: Law and New Approaches to Governance in the European Union, in: European Law Journal, Vol.8 (2002) No.1, p.1.

2 The relation between the OMC procedure of the Employment Title (Title VIII EC Treaty) and the legislation based on the social provisions of the EC Treaty (Title XI) is a complex one; European legislation based on the social provisions aims at regulating the employment relation; although not necessarily aiming at tackling unemployment it may influence the availabitility of job opportunities on the labour markets, such as, for instance, the regulation of working time and part-time work by the Directives 91/383/EEC and 97/81/EC. Moreover, the limited amount of European labour law legislation seems to be increasingly used as a tool to reach the objectives of European employment policy. See N. Bruun, The European Employment Strategy and the 'Acquis Communitaire' of Labour Law, in: The International Journal of Comparative Labour Law and Industrial Relations (2001), Vol.17, No.3, p.309.

3 When considered at EU level, they are addressed in the Broad Economic Policy Guidelines, the Cologne Process' Macroeconomic Dialogue, and/or by the European Central Bank. 
European level of policy choices - without broad scope of political debate - that otherwise would be taken at lower levels, and 'open' not in the sense of assumed increased participation of stakeholders and public scrutiny, but merely as being openended in its outcomes (section 4). Nevertheless, the OMC has some potential to be 'decentralised', on the one hand, by adjusting its institutional framework, and on the other hand, by 'territorializing' the European Employment Strategy through the search of better synergies between employment policy and territorial politics (section 5).

\section{The European Employment Strategy, the mother of the OMC}

The idea of a European Employment Strategy (EES) had been raised by the Delors White Paper on Growth, Competitiveness and Employment (1993) but it was at the Essen European Council meeting of December 1994 that a decision process on employment was actually initiated at Community level. Inspired by the convergence process in the economic field, the process was further strengthened into a 'guidelines procedure' and constitutionalised by the Amsterdam Treaty, and first put into practice following the Luxembourg Summit of 1997, even before the new Treaty had been ratified.

The creation of such a guidelines procedure was a compromise between on the one hand the idea that European intervention based on the Community method and a real common European employment policy would be too intrusive into the member states' competencies, and on the other hand, the awareness that high and rising unemployment represented a major social and economic challenge for Europe. ${ }^{4}$ Moreover, although there was no clear evidence of a causal relation between the efforts to meet the convergence criteria for monetary union and rising unemployment, European decisionmakers feared that public opinion's perception of such a relation would delegitimise EMU. ${ }^{5}$ The introduction of an Employment Title in the Amsterdam Treaty was, therefore, a unifying and popular project easy to 'sell' to European citizens. ${ }^{6}$ A guidelines procedure, based on the idea of sharing of experience and reform experimentation -inspired by the idea of benchmarking often used in industry, and already applied in the convergence process for EMU $-^{7}$ allowed working towards common goals at European level without encroaching on national sovereignty. ${ }^{8}$

According to Article 128 TEC, the OMC employment procedure begins with the

4 D. Trubek and J. Mosher, New Governance, EU Employment Policy, and the European Social Model, in: Jean Monnet Working Paper No.6/01, Symposium: The Commission White Paper on Governance, New York University School of Law, 2001, pp.4-11.

5 C. Pierson, A. Forster and E. Jones, The politics of Europe : (un)employment ambivalence, in : B. Towers and M. Terry, Industrial Relations Journal European Annual Review 1997, p.7.

6 J. Goetschy, The European employment strategy from Amsterdam to Stockholm: has it reached its cruising speed yet?, in: Industrial Relations Journal Vol.32 (2001) No.5, p.401.

7 The idea to use benchmarking for European policies had been defended by the European Round Table of Industrialists. K. Sisson and P. Marginson, Benchmarking and the 'Europeanisation' of social Policy, in ESRC One Europe or Several? Prgramme Briefing Note, 3/01, 2001.

8 H. Wallace, The Changing Politics of the European Union: An Overview, in Journal of Common Market Studies, vol.39 (2001) No.4, p.581. 
Commission developing general ideas about the best employment strategy for EU member states to pursue. Although the Commission develops these ideas in discussions with the Council of Ministers, Member States, the relevant social actors, such as unions and employers' organisations and academics, it is the primary administrator of the process. These general ideas are made concrete in the form of annual guidelines which the Member States 'shall take into account in their employment policies'. They are proposed by the Commission and, after consultation of the European Parliament, the Economic and Social Committee, the Committee of the Regions and the Employment Committee, ${ }^{9}$ modified and approved by the Labour and Social Affairs Council. Each Member State is subsequently to make an annual report (the National Action Plan, NAP) on 'the principal measures taken to implement its employment policy in the light of the guidelines for employment', outlining how it plans to respond to the guidelines and what progress has been made. The NAPs are sent to the Commission and the Council which prepare a joint report to the European Council of that year. Moreover, on the basis of this analysis and at the initiative of the Commission, the Council may make (non-binding) recommendations to Member States concerning their employment policies. ${ }^{10}$

This guidelines procedure, also called 'the Luxembourg process' following the summit that first made the procedure applicable, was placed by the Cologne Summit under the heading of 'the European Employment Pact' - linking 'the Luxembourg process' to 'the Cardiff process', i.e. a benchmarking process on policy reform regarding capital, product and labour markets, and to the 'macroeconomic dialogue' consisting of biannual discussions of the policy-mix at EU level between the social partners, the European Central Bank, the Commission and the Council. However, it is the merit of the Lisbon Summit to have defined the OMC explicitly as a new policy instrument, and to embed the employment OMC in a broader coordination of different policy fields. The OMC should apply to several policy fields: employment ('Luxembourg process'), economic reform ('Cardiff process'), innovation and the knowledge society, the fight against social exclusion, education policy and life long learning; and could in the future be applied to other fields such as the modernisation of social security, as it is by now the case with an OMC on pension reform. Moreover, the Lisbon Summit has created a new European Council (besides the two taking place traditionally in June and December) which should be devoted to economic and social affairs and will be held every spring. This Spring Summit aims at combining the European Broad Economic Policy Guidelines with the Employment Guidelines, the Lifelong learning policy, the social protection reform and the economic structural reforms.

While it is not the aim here to analyse the precise interaction between these processes, it is worth to note that the OMC concept does not always imply the same procedure, i.e. its characteristics vary according to the policy field. As defined by the Lisbon Summit, OMC procedures have in common the fixing of guidelines; the establishment of quantitative and qualitative indicators and benchmarks; the translation

\footnotetext{
9 See below.

10 The 'employment package' presented each year by the European Council consists in the Joint Employment Report, the Employment Guidelines and the Recommendations to the Member States.
} 
of these guidelines in national and regional policies; and a periodic monitoring, evaluation and peer review (European Council Presidency Conclusions 23/24 March 2000). ${ }^{11} \quad$ However, while the economic and employment policy co-ordination are Treaty-based processes, the other OMCs are not. Moreover those two OMC procedures include the possibility to issue recommendations, whereas the others do not. In addition, the periodicity of drafting guidelines differs, as well as the specificity of the quantitative and qualitative targets. Finally, decentralised participation in the OMC differs according to the policy sector.

\section{Decentralised participation in the EES; rhetoric and reality}

\subsection{About radicalising subsidiarity and directly-deliberative polyarchy}

The OMC has been heralded for its decentralised approach. At a minimum level it means the respect of national diversity by leaving policy competency to the national level and not imposing a centralised European common policy. 'Open' can refer to the open-ended character of the policy aims - which are periodically adjusted - or to the flexibility allowed to the Member States in the way to reach desired policy outcomes. ${ }^{12}$ But at a maximum level, 'open' also means policy making through the involvement of a multiplicity of actors, and through horizontal interaction rather than through vertical hierarchy. According to the Lisbon Conclusions defining the OMC, 'a fully decentralised approach will be applied in line with the principle of subsidiarity in which the Union, the Member States, the regional and local levels, as well as the social partners and civil society, will be actively involved, using variable forms of partnership (stress added)'. ${ }^{13}$ More than any other policy instrument, the OMC pleads for decentralism in both vertical and horizontal terms. It has even been argued that the OMC constitutes a radicalisation of the subsidiarity principle. Subsidiarity is said to be 'a static principle with its focus on what level of government at a particular time of rule formation in the policy process and with a continuing emphasis on hierarchy of structures. The OMC, being focused on horizontal learning processes and peer pressure where individual action runs counter to broadly accepted principles, is dynamic in nature, heterarchical, decentred as a modus operandi and without any particular rule or

11 Using this definition, one could not label as 'OMC' the benchmarking encouraged by the creation of a Social Protection Committee set up during the Finnish Presidency at the end of 1999 and enshrined in Article 144 of the Nice Treaty, since it does not provide a guidelines procedure; whereas one can talk of an OMC regarding Pension Reform and Social Exclusion, where such a procedure has been established.

12 D. Hodson and I. Maher, The Open Method as a New Mode of Governance: The Case of Soft Economic Policy Co-ordination, in Journal of Common Market Studies, Vol. 39 (2001) No.4, p.724.

13 Presidency Conclusions, Lisbon European Council, March 23-24, 2000 . At http://europa.eu.int/council/off/conclu/mar2000/index.htm 
single policy objective as an objective. ${ }^{14}$ Yet, precisely due to this 'fluid decentralist character', one can question whether the OMC can be seen as a guarantee for (or radicalisation of) subsidiarity. The OMC recognizes the interrelation between different spheres, promoting interaction between different levels of power and spheres of action, but it does not define the level of power that is most appropriate and does not as such privilege lower decision-making levels. ${ }^{15}$

Others have suggested that the OMC could be an example of 'democratic experimentalism' or 'directly-deliberative polyarchy'. ${ }^{16}$ This democratic ideal is based on the idea that 'local-, or more exactly, lower-level actors (nation state or national peak organizations of various kinds within the EU; regions, provinces or sub-national associations within these, and so on down to the level of whatever kind of neighbourhood the problem in question makes relevant) are granted autonomy to experiment with solutions of their own devising within broadly defined areas of public policy. In return they furnish central or higher-level units with rich information regarding their goals as well as the progress they are making towards achieving them, and agree to respect in their actions framework rights of democratic procedure...' ${ }^{17}$ The system is 'directly-deliberative' since 'citizens must examine their own choices in the light of the relevant deliberations and experiences of others ${ }^{18}$ (stress added), in contrast to other discursive ideas of democracy of deliberation at a distance, by an administrative or political elite. The system is 'polyarchic' due to the permanent dis-equilibrium created by the grant of substantial powers of initiative to lower-level units. ${ }^{19}$

It is suggested that the OMC as 'a way of networking decentralised decision-making units by a common system of benchmarking' can be identified as a form of directlydeliberative polyarchy. It would constitute a mode of governance relying on local deliberation enabling stakeholders to directly participate - and not only on expert deliberation within European regulatory agencies or committees - and it would offer a solution to the question of how a multitude of decision-making arenas can be coordinated without exerting hierarchical control that would lead to stalemate. ${ }^{20}$

14 D. Hodson and I. Maher, The Open Method as a New Mode of Governance, p.728; with reference to N. Lebessis and J. Paterson (2001), Developing New Modes of Governance, in O. De Schutter, N. Lebessis and J. Paterson (eds), Governance in the European Union, Luxembourg, Official Publications, p.292.

For a comparable criticism, see C. De la Porte, P. Pochet and G. Room, Social benchmarking, policy making and new governance in the EU, in Journal of European Social Policy (2001) Vol.11, No.4, p.294.

16 B. Eberlein and D. Kerwer, Theorising the New Modes of European Union Governance, in European Integration online Papers (EIoP) Vol.6 (2002) No.5; at http://eiop.or.at/eiop/texte/2002$\underline{005 \mathrm{a} \cdot \mathrm{htm}}$

17 O. Gerstenberg and C. Sabel, Directly-Deliberative Polyarchy: An Institutional Ideal for Europe?, in C. Joerges and R. Dehousse (eds), Good Governance in Europe's Integrated Market, Oxford, Oxford University Press, 2002, p.291.

J. Cohen and C. Sabel, Directly-Deliberative Polyarchy, in European Law Journal Vol.3 (1997), No.4, p.314.

19 O. Gerstenberg and C. Sabel, Directly-Deliberative Polyarchy: An Institutional Ideal for Europe?, p.292.

20 B. Eberlein and D. Kerwer, Theorising the New Modes of European Union Governance, p.10. 
However, more empirically based analyses of the OMC describe the process much more as a top-down standard-setting through specialised committees rather than a bottom-up deliberation, recognising the diversity of national situations, ensuring local participation and public scrutiny. ${ }^{21}$

In the following section I will have a closer look on how decentralised participation is organised in the EES. Although the OMC is a circular procedure in which assessment of the implementation stage is supposed to influence the periodical redefinition of the benchmarks at European level, it is useful - for the simple aim of clarification - to distinguish between, on the one hand, the decentralised participation (functional and territorial) in the peer review process constituted by the guidelines procedure (3.2), and on the other hand, the elements of decentralism in the implementation of the European employment policy based on the guidelines (3.3).

\subsection{Decentralised participation in the peer review process}

According to Article 128 al.2 TEC the Council, when deciding on the European Employment Guidelines, should consult the European Economic and Social Committee and the Committee of the Regions (in addition to the consultation of the European Parliament and the Employment Committee). Moreover, according to Article 130 TEC, the Employment Committee in fulfilling its mandate shall consult management and labour, i.e. the European social partners' confederations. It is worth to stress that this implies only an indirect consultation of the European social partners' organisations; it is the advisory Employment Committee which, on its turn, is asked to consult the European social partners; Article 128 does not require a direct consultation of management and labour by the Commission or Council on the Employment Guidelines, as this is, for instance, the case for legislative initiatives via the social dialogue procedure of Article 138 TEC. $^{22}$

Moreover, these consultation procedures organised at European level are weak as a guarantee for a fully decentralised approach. The OMC is a circular process in which the assessment of 'local' differences in implementation are supposed to be made in

21 C. Barbier, C. de la Porte and P. Pochet, European Briefing, in: Journal of European Social Policy Vol.12 (2002) No.3, p.242; R. Kaiser and H. Prange, A new concept of deepening European integration? The European Research Area and the emerging role of policy coordination in a multilevel governance system, in European Integration online Papers (EIoP) Vol.6 (2002) No.18; at http://eiop.or.at/eiop/texte/2002-018a.htm; and P. Nanz and C. de la Porte, OMC - An important tool to improve transparency and democratic participation? The case of pension reform from the perspective of deliberative democracy; in Journal of European Public Policy (forthcoming 2004).

One could wonder whether the requirement to consult management and labour under the social dialogue procedure of Article 138 TEC shouldn't also apply to the drafting of the Employment Guidelines. Article 138 TEC requires consultation on 'initiatives in the social field'. Following a Communication of the Commission this has always been interpreted as 'legislative initiatives'. This interpretation has never been contested by the social partners. Yet, if Article $138 \mathrm{EC}$ is read as 'initiatives tout court' one can question whether the procedure shouldn't also apply to the Employment guidelines. 
National Action Plans which are then reviewed at European level, in order to re-adjust the Employment Guidelines. It is striking then that Article 128 al.3, which asks the Member States to provide the Council and the Commission with an annual report, does not make any reference to the role of sub-national public authorities and social partners in drafting the NAPs. In fact, the drafting of the NAPs has essentially been a governmental process. ${ }^{23}$ The social partners are consulted but only at national level. Moreover, consultation takes mainly place at a technocratic level, which is in contrast with the experience in negotiating social pacts at national level, where top representatives of the union and employer's organisations are invariably the protagonists. ${ }^{24}$ Seen from the bottom up, civil society actors are not aware enough of the OMC process to mobilise on it, or they may feel that they are not gaining much from contributing to the NAPs which are seen more as a description of government policy than as an actual plan of future action. ${ }^{25}$ The involvement of sub-national public authorities in the drafting of the NAPs has repeatedly been described as scarce. ${ }^{26}$

Also at the stage of assessing the NAPs at European level, the decentralised involvement is limited. Article 128 al. 4 only requires that the Council, when examining the implementation of employment policies in the member states, shall take into account the views of the Employment Committee, which implies indirectly (Article 130) a consultation of the European social partners associations.

Both in the assessment of NAPs and in the drafting of new guidelines the OMC process is controlled by the Commission, which has the initiative, and the Council, which takes the final decision; with an important role for the Employment Committee. ${ }^{27}$ According to Art 130 TEC this committee is composed of two representatives from each member state (i.e. from the national ministries) and two from the Commission. Although the Committee is formally advisory it has great influence in that its proposals are often identical with the eventual Council decisions. ${ }^{28}$ From interviews it results that most Committee members consider their work as rather closed to the broader public and to other interested parties such as executive agencies and actors at_sub-national levels. ${ }^{29}$ Social partners are consulted according to the Treaty obligation of Article 130 and may have some influence via informal meetings of the Committee. Yet, Committee members speak and reflect in terms of political mandates given to them 'back home',

E. Léonard, Industrial Relations and the Regulation of Employment in Europe, in European Journal of Industrial Relations Vol.7 (2001) No.1, p.32; and J. Goetschy, The European employment strategy from Amsterdam to Stockholm, p.410.

D. Foden, The Role of Social Partners in the European Employment Strategy, in Transfer Vol.5 (1999) No.4, p.215.

25 K. Jacobsson and A. Vifell, Integration by deliberation? Dynamics of Soft Regulation in the Case of EU Employment Policy, Paper presented at the ECPR Conference, 26-28 September 2002, Bordeaux, p.23.

D. Trubek and J. Mosher, New Governance, EU Employment Policy, and the European Social Model, in: Jean Monnet Working Paper No.6/01, Symposium: The Commission White Paper on Governance, New York University School of Law, 2001, p.22-23.

27 Regarding the issuing of Recommendations to the Member States, the process is entirely controlled by the Commission and the Council. The Treaty (Article 128 al.4 ) does not even require the consultation of the Employment Committee. 
i.e. they have to respect the negotiated national standpoint agreed upon within the national ministry. ${ }^{30}$

It is, therefore, argued that the OMC has 'developed much as a transgovernmental network, anonymous and closed in relation to national publics as well as to the domestic political process and involving a fairly small number of central civil servants who are not well integrated in the making and implementation of domestic policy', ${ }^{31}$ and the approach of the Commission has been described as 'a top down one (the regional level should simply ensure implementation of the EES) and not a bottom up one (which recognizes the diversity of national situations, the need for experimentation and public scrutiny). ${ }^{32}$

Comparable criticism has been formulated regarding OMC procedures in other fields. Initial empirical findings on the $\mathrm{OMC}$ in the area of Research \& Development, for instance, show that benchmarks result not that much from experience of decentralised experimental learning, but are rather imposed by the coordinating centre, in particular the European Commission. ${ }^{33}$ More optimism is expressed regarding the involvement of civil society organisations in the OMC social inclusion, in particular regarding the involvement of European associations active in this field. ${ }^{34}$ Yet, even for the OMC on social inclusion, the assessment of the involvement of the social partners and NGOs at national level, i.e. in the elaboration of the NAPs, is more shaded, and there appears no sufficient evidence of the effective mobilization of regional and local authorities in this $\mathrm{OMC}^{35}$

\subsection{Decentralised participation in the implementation of the EES}

While during the first years of the EES most energy seems to have been spent on the drafting of the guidelines, the Summit of Barcelona 2002 - the second Spring Summit

30

31 . 12

K. Jacobsson (2001), Innovations in EU Governance; The Case of Employment Policy Coordination, SCORE Report 2001/12, p.9.

32 C. Barbier, C. de la Porte and P. Pochet, European Briefing, in: Journal of European Social Policy Vol.12 (2002) No.3, p.242.

33 R. Kaiser and H. Prange, A new concept of deepening European integration? The European Research Area and the emerging role of policy coordination in a multi-level governance system, in European Integration online Papers (EIoP) Vol.6 (2002) No.18; at http://eiop.or.at/eiop/texte/2002018a.htm D. Kerwer, in a comment added to this paper, notes that, if these findings are confirmed in other fields, the viability of 'democratic experimentalism' in the form of EU's OMC - he had argued for previously - should be questioned. See B. Eberlein and D. Kerwer, Theorising the New Modes of European Union Governance.

34 K. Armstrong, Tackling Social Exclusion Through OMC: Reshaping the Boundaries of EU Governance, in T. Börzel and R. Cichowski (eds.) State of the Union: Law, Politics and Society (Vol. 6), Oxford: Oxford University Press, 2003 (forthcoming), pp.170-94. inclusion process', in Journal of European Social Policy Vol.12 (2002) No.3, p.236. 
on economic and social issues since the institution was introduced in Lisbon - stated that 'the focus must be on action for implementation, rather than on the annual elaboration of guidelines'. In fact, the drafting and monitoring of the guidelines implies (both for the Commission and the member states) a high bureaucratic workload, not at least because of the high number of guidelines. ${ }^{36}$ The energy spent on the formal monitoring and (re-)drafting of guidelines may not be in proportion to the efforts done to implement the policy proposed in the guidelines. In the same line we should not only ask how sub-national and civil society actors participate in the drafting and monitoring of the guidelines but also how they actually contribute to implement the policy proposed in the EES. One can distinguish between how such participation in the implementation is envisaged in the Employment Title (3.3.1) and in the Guidelines (3.3.2.).

\subsubsection{Participation in implementation according to the Employment Title}

Besides being consulted via the ESC or the COR or by the Employment Committee, sub-national and civil society actors are not attributed a particular role under the European Employment Title. The member states are the core actors of employment policy, and the EES is above all ${ }^{37}$ based on the fact that the 'Member States,...., shall regard promoting employment as a matter of common concern and shall coordinate their action in this respect within the Council...' (Article 126 al.2 TEC). However, defining this coordination-principle the Treaty also stipulates that the Member States should do so 'having regard to national practices related to the responsibilities of management and labour'. Put differently, the Treaty recognises explicitly the autonomy and role of the social partners in employment policy at national level.

Nevertheless, besides this explicit recognition of the role of the social partners at national level, the Employment Title is characterised by its omissions regarding the role of multiple decentralised actors in implementing employment policy.

First of all, while the member states, in co-ordinating their national employment policies, should have 'regard to national practices related to the responsibilities of management and labour', there is no such equivalent Treaty stipulation recognizing the role of regional and local authorities. Yet, regional and local authorities play a primary role in employment policies. Even when employment policies are designed centrally they are most often implemented through employment and social services organised regionally or locally. Moreover, decentralisation in many of the Member States has led to sub-national, in particular regional, authorities having important competencies in employment matters.

Second, the social partners may contribute to the implementation of the EES at various levels. Not all of these multiple levels seem to be covered by the wording

\footnotetext{
36 C. Barbier, C. de la Porte and P. Pochet, European Briefing, p. 241.

37 According to Article 127 TEC the 'Community shall contribute to a high level of employment by encouraging cooperation between the Member States and by supporting and, if necessary, complementing their action.' However, 'in doing so, the competences of the Member States shall be respected'. Article 129 specifies that the Council may adopt incentive measures to encourage cooperation between Member States, and support their action, in particular by recourse to pilot projects.
} 
'national practices related to the responsibilities of management and labour', and even if one accepts a broad interpretation of this wording, the phrasing that the member states 'should have regard to' these national practices can hardly be said to be a pro-active approach to encourage decentralised participation. National social partners can contribute to the implementation of the EES by agreeing on national tripartite social pacts, ${ }^{38}$ or by signing bipartite social agreements. 'Traditional' industrial relations also develop through agreements and joint action at sectoral and enterprise level. Yet, one may also wonder whether "national practices related to the responsibilities of management and labour' should also refer to interactions between social partners and regional and local authorities, given the increasing role of the latter in employment and social matters. Although consultation structures and inter-professional negotiations at regional and local levels are still weak, ${ }^{39}$ local actors - both public and private - have generally argued for a strengthening of such structures, in particular at regional level, given the increased employment competencies at this level. ${ }^{40}$

In any case, the reference to 'national practices' does not include a recognition of the role in the EES for management and labour organised at European level. At first sight this might make sense given that the EES is simply supposed to be a coordination of national policies. Yet, at a closer look, the absence of any reference to the role of the social partners organised at European level should not surprise any less than the lack of a reference to the role of regional and local authorities. The European social dialogue (Articles 138-139 TEC) has assigned to the European social partners a prominent role in all Community legislative initiatives in the social field. As mentioned in the introduction of this chapter, such Community legislation in the social field (which can take the form of European collective agreements), is likely to influence the labour market and has consequences for national employment policies. By not taking into account this role of the European social partners, the Employment Title does not rightly reflect the framework in which an EES should develop.

One may conclude that the Employment Title does not provide a comprehensive framework for what might be a European employment policy in a multi-level context. The Treaty provisions read as an EES built on the member states, and not as a European employment policy built on a multitude of actors in a multi-level polity, including regional and local authorities and civil society organisations organised at European, regional and local level (in addition to 'traditional' national, sectoral and firm-level social partners associations). If one can read in the Employment Title the intentions of the member states when creating a European employment policy, there are few signs to

38 See, for instance, the Irish national social partnership approach to macro-economic policy, income distribution and structural adjustments to implement the European employment strategy; Séamus Ó Móráin, The European Employment Strategy . a Consideration of Social Partnership and Related Matters in the Irish Context, in: The International Journal of Comparative Labour Law and Industrial Relations (2000) Vol.16, No.1, p.85-101. See also below, footnote 79.

The 'traditional' industrial relations systems are mainly organised at interprofessional, sectoral and enterprise level. See below.

This results, for instance, from a consultation of regional and local actors organised by the European Commission on its communication 'Acting Locally for Employment - A Local dimension for the European Employment Policy' COM (2000) 196. The results of the consultation are summerised in Annex 2 added to the Commission Communication 'Strengthening the local dimension of the European Employment Strategy’, COM (2001) 629 final, of 06/11/2001. 
believe that the OMC was intended to be a prime example of a fully decentralised approach, a radicalisation of subsidiarity ${ }^{41}$ or the realisation of the democratic experimentalist dream.

\subsubsection{Participation in implementation according to the Employment Guidelines}

The institutional provisions of the Employment Title are in contrast with the strong rhetoric on decentralism that has pervaded the policy documents that result from the EES. It is worth here to have a brief look at the content of the EES. Although the content of the guidelines changed considerable this year (see below), it is worth to have a look at how participation had been envisaged until now.

For five years the EES - based on an annual variable number of new and re-drafted guidelines - has been build around 'four pillars', namely Employability, Entrepreneurship, Adaptability, and Equal Opportunities. ${ }^{42}$ 'Improving Employability' aims at improving access of the unemployed (in particular youth and the long-term unemployed) to the labour market, both through preventive action, in particular by providing training, and through 'activation policies' by reviewing tax and benefit systems. The 'Entrepreneurship' pillar aims at making it easier to start up and run business, with a particular focus on SMEs, the knowledge-based sector and services. The activities include encouraging greater entrepreneurial awareness across society, reducing administrative constraints and reforming taxation. 'Improving Adaptability' implies the modernisation of work organisation in order to reconcile more flexibility with security and high occupational status. Finally, the 'Equal Opportunities' pillar includes gender mainstreaming, tackling gender gaps in unemployment rates, encouraging gender pay equality and reconciling work and family life through the design of family-friendly policies.

The Guidelines stress explicitly the role of both social partners and regional and local authorities. Yet, the role attributed to them differs according to the different 'pillars'. The social partners, for instance, have traditionally a negotiating role in the organisation of the working environment and thus have their most prominent role under the heading of Adaptability. Regarding regional and local authorities on the contrary, the Guidelines recognise in particular their role in creating the conditions to encourage Entrepreneurship.

\footnotetext{
41 In fact, when giving a brief introduction to the EES on its website, the Commission indicates subsidiarity as one of the advantages of the OMC, but sticks to the most restrictive definition of the concept, namely subsidiarity is said to be an advantage of OMC since 'the method establishes an equilibrium between European Union level co-ordination in the definition of common objectives and outcomes, and Member States' responsibilities in deciding the detailed content of action. The definition of the means and conditions under which programmes and policies are implemented is left to a large extent to individual Member States, who are responsible for their employment policy under the EU Treaty.' No reference is made to the sub-national or to the horizontal dimension of subsidiarity. See http://www.europa.eu.int/comm/employment_social/employment_strategy/index_en.htm\#
}

42 The following description is based on the employment guidelines 2002. Council Decision 2002/177/EC of 18 February 2002 on guidelines for Member States' employment policies for the year 2002, Official Journal L 060 , 01/03/2002 P. 0060 - 0069 
However, there is also a difference in the intensity with which the Guidelines refer to vertical and horizontal decentralism; namely, the role of the social partners is much more stressed than that of the regional and local authorities. In particular since the 2001 Guidelines, i.e. those following the Lisbon and Feira summits, particular attention has been paid to the role of the social partners. ${ }^{43}$ One should note that the Feira summit had been preceded by a High Level Forum to discuss the respective contribution of the EU institutions and the social partners in the Lisbon strategy and the EES. The social partners presented on that occasion a joint declaration on their own role.

Both the 2001 and the 2002 Guidelines, define as a 'horizontal objective' (i.e. crosscutting the four pillars) the development of a comprehensive partnership with the social partners. The social partners 'at all levels' are invited to play a more prominent role in the EES and are expected to create 'a process within the process'. At national level, they are invited to implement the guidelines 'in accordance with their national traditions and practices' by identifying the issues they want to negotiate on, and to report subsequently on the results of such negotiation in context of the NAPs. Also the social partners at European level are invited to define their own contribution. In addition they are requested to monitor, encourage and support efforts undertaken at national level. Finally the horizontal objective encourages the social partners to develop their own benchmarking exercise by inviting them 'to develop appropriate indicators and benchmarks and supporting statistical databases to measure progress in the actions for which they are responsible'.

With regard to Adaptability the social partners have been given exclusive responsibility for the implementation of two guidelines, namely guideline 13 concerning the modernisation of work organisation and guideline 15 on the contribution of education and lifelong learning to adaptability. On both issues an annual report is expected from them on the negotiations achieved and on their implementation.

Other guidelines invite the Member States '(where appropriate) in partnership with the social partners' to combat emerging bottlenecks (G6), combat undeclared work (G9), take part in local action for employment (G10), tackle gender gaps (G17) and reconcile work and family life (G18).

In comparison, the explicit recognition of the role of regional and local authorities is much more limited. Guidelines 10 and 11, relating to Entrepreneurship, pay attention to 'regional and local action for employment':

10. All actors at the regional and local levels, including the social partners, must be mobilised to implement the European Employment Strategy by identifying the potential of job creation at local level and strengthening partnerships to this end. 11. Member States will:

- take into account, where appropriate, in their overall employment policy the regional development dimension,

43 The Santa Maria da Feira European Council on 19 and 20 June 2000 invited the social partners to play a more prominent role in defining, implementing and evaluating the employment guidelines which depend on them, focusing particularly on modernising work organisation, lifelong learning and increasing the employment rate, particularly for women. 
- encourage local and regional authorities to develop strategies for employment in order to exploit fully the possibilities offered by job creation at local level and promote partnerships to this end with all the actors concerned, including the representatives of civil society (stress added)

This is the only Guideline that makes explicitly reference to local and regional authorities. Remarkable there is no reference to sub-national authorities under the Employability pillar, whereas important levers for 'activation policies', such as tax and benefit systems, may be in their hands and training and employment services are in particularly organised at regional and local level. Regarding Adaptability, Guideline 12 states that 'in order to promote the modernisation of work organisation and forms of work, which inter alia contribute to improvements in quality in work, a strong partnership should be developed at all appropriate levels (European, national, sectoral, local and enterprise levels)'. Although this seems to suggest both a horizontal and vertical decentralised approach, the regional level is remarkably absent in the enumeration.

It results in fact from a consultation of regional and local actors, organised by the European Commission, that the involvement of sub-national actors in the EES has been considered 'largely insufficient'. ${ }^{44}$ On the one hand, local authorities and actors are often confined to implementing measures decided at national or regional level. On the other hand, the EES, NAPs, and structural Funds programmes (in particular the European Social Fund, aimed at combating unemployment) are not sufficiently wellknown at regional and local levels. ${ }^{45}$ Only in the limited cases where the Community can directly intervene locally on employment issues, via Community Initiatives and Innovative Actions (Article 129 EC Treaty), the EES has some visibility at local level. ${ }^{46}$ The problematic result is twofold. On the one hand, there is a lack of local employment strategies - as opposed to isolated initiatives and projects - built on the Employment Guidelines. $^{47}$ On the other hand, given the lack of decentralised involvement in the drafting of the NAPs (see above), the Guidelines do finally not take enough into account the territorial and local dimension and diversity.

\section{OMC, an Open Method of Centralisation?}

As results from the previous sections the OMC can hardly be said to respect a fully decentralised approach. In institutional terms, the Treaty does not provide a comprehensive framework for a benchmarking process built from the bottom-up. In practical terms, both in the implementation of the employment policy based on the

\footnotetext{
44 Commission Communication 'Strengthening the local dimension of the European Employment Strategy’, COM (2001) 629 final, of 06/11/2001.

45 Ibid, p.9.

46 Ibid, p.9.

47 See also section 5 on the territorialization of employment policies via local employment strategies based on Territorial Employment Pacts of Local Action Plans.
} 
guidelines and in the peer review process to assess and redraft annually the guidelines, the involvement of the social partners, civil society and regional and local authorities is much weaker than what the rhetoric suggests. Without such a decentralised participation, the definition of benchmarks at European level may be rather a threat for than a radicalisation of the principle of subsidiarity. The practice of the Employment OMC shows a process through which substantive policy-priorities are set at EU level in a rather technocratic manner, without broad decentralised stakeholders involvement or public and parliamentary debate. Such a top-down approach cannot be the best guarantee for respecting national and sub-national diversity.

Although the real impact of the EES on national employment policies remains subject of debate, ${ }^{48}$ 'the annual exercise imposed by the EU at the very least contributes to the diffusion of a framework defining in what terms and with what priorities debates on employment should take place in the member states'. ${ }^{49}$ States are no longer free to determine national policy but must work within officially recognised Community Guidelines which have taken on a normative status. ${ }^{50}$

The Guidelines take the form of a Decision which certainly reads as if intended to have normative effect. ${ }^{51}$ Each year, the sole article of that Decision - with the guidelines annexed - has stated that member states 'shall' take the guidelines into account in their employment policies. The Recommendations, addressed to individual member states, give even more the impression of dictating what the content of member states' employment policies should be. ${ }^{52}$ The Commission makes more than 50 Recommendations to the member states annually. The individual recommendations to the member states tend to a great extent to be repeated from year to year, which effectively put the Member States under pressure to comply. ${ }^{53}$

For sure, each year the introductory considerations to the Guidelines state that 'the implementation of the Guidelines may vary according to their nature, the parties to whom they are addressed and the different situations in the member states. They should respect the principle of subsidiarity and member states' responsibilities with regard to employment'. Moreover, 'in implementing the employment guidelines, member states should be able to take regional situations into account..., 54

Nevertheless, the scope for diversity at the implementation stage only exists within

E.g. P. Syrpis, Legitimising European Governance: Taking Subsidiarity Seriously within the Open Method of Coordination, EUI Working Paper 2002, p.40.

49 E. Léonard, Industrial Relations and the Regulation of Employment in Europe, in: European Journal of Industrial Relations Vol.7 (2001) No.1, p.34.

50 E. Szyszczak, The Evolving European Employment Strategy, in Shaw (ed), Social Law and Policy in an Evolving European Union, Hart, Oxford, 2000, p.211.

51 P. Syrpis, Legitimising European Governance, p.37.

52 M. Biagi, The Implementation of the Amsterdam Treaty with Regard to Employment: Coordination or Convergence?, in: The International Journal of Comparative Labour Law and Industrial Relations (1998) Vol.14, No.4, p.327; and D. Ashiagbor, EMU and the Shift in the European Labour Law Agenda: From 'Social Policy' to 'Employment Policy', in European Law Journal Vol.7 (2002) No.3, p163.

C. de la Porte and P. Pochet, Supple Co-ordination at EU level, in C. de la Porte and P. Pochet (eds), Building Social Europe Through the Open Method of Co-ordination, PIE/Peter Lang, 2001. 
the normative framework established at European level, which includes important policy choices - such as those exemplified by the four pillar structure.

In fact, as soon as the Commission acknowledged responsibility for employment, following the Dublin Council of 14 December 1996, it set itself frenetically at work producing the framework of European employment policy around the concepts of entrepreneurship, employability, adaptability and equal opportunities. ${ }^{55}$ These principles changed little through the negotiations with the other institutions, the member states and the social partners, leading by December 1997 to the first Employment Guidelines formally adopted by the Council. ${ }^{56}$ The four pillars, which were agreed upon in a top-down manner, ${ }^{57}$ became the core features of the EES for the five years to come and imply for some countries important structural reforms, which are not necessarily in tune with their dominant national policy objectives or traditions, 58

These four pillars are no 'neutral decision', but imply important policy choices. The employment policy model behind the EES is a compromise between the liberal and the Nordic models. On the labour demand side the EES, with its attention for entrepreneurship and adaptability, is inspired by the liberal model emphasising labour market deregulation and tax reductions; whereas on the labour supply side the EES is inspired by the Nordic model focusing on employability via training and active labour market policies. ${ }^{59}$ As a consequence, the 'adjustments costs' are much higher for the central continental and the Southern countries. This is illustrated by the number of Recommendations addressed to the member states; the continental and Southern countries are (roughly) twice as much the subject of Recommendations compared to the Nordic countries, the UK and Ireland. ${ }^{60}$ The OMC seems in fact to pay little consideration to the fact that countries whose employment policy is particularly distant from the one put forward by the EU will most likely face enormous political problems in implementing the guidelines and recommendations. ${ }^{61}$

If we recall that the $\mathrm{OMC}$ has been set up as an alternative to the Community method; to avoid centralisation, to leave decision-making power - in particular in relation to social policy - to the member states while ensuring co-ordination, the experience of the EES may question whether the OMC could really be, as suggested, the

Commission (1997), Employment in Europe: Countdown to the Jobs Summit, 20-21 November 1997, IP/97/835, 1 October 1997.

C. Pierson, A. Forster and E. Jones, The Politics of Europe: (un) employment ambivalence, pp.9-11; and M. Biagi, The Implementation of the Amsterdam Treaty with Regard to Employment, p329.

C. de la Porte, Is the Open Method of Coordination Appropriate for Organising Activities at European Level in Sensitive Policy Areas?, in European Law Journal Vol.8 (2002) No.1, p.46.

C. De la Porte, P. Pochet and G. Room, Social benchmarking, policy making and new governance in the EU, in Journal of European Social Policy (2001) Vol.11, No.4, p.295. Thus the agreed objective to reach an overall employment rate of 70 percent by 2010 is likely to have a particularly strong impact on the "conservative" welfare states, whereas it is not at all that clear how they may be able to reach this target.

59 F. Bertozzi and G. Bonoli, Europeanisation and the convergence of national social and employment policies. What can the open method of co-ordination achieve?, paper presented at the ECPR Joint Sessions, 22-27 March 2002,p.9. Ibid, p.9. 
tool to 'help the European social model to survive', ${ }^{2}$ by reconciling European objectives with (sub-)national diversity.

Regarding the OMC as a tool to help the European social model to survive, three aspects should, in particular, be taken into account.

First, there are strong diversities in national welfare traditions. Benchmarking in the social field at European level should be able to respect these diversities and recognise its added value, i.e. it provides the basis for exchange of best practice and experience without the need to impose a top-down solution. The OMCs in the employment and social fields are criticised for having been inspired too strongly by the model of the broad economic guidelines. The OMC in economic policy was realised in the context of a 'cultural frame which provided the agreed, if not entirely fixed, paradigm of sound money and sound finance'. ${ }^{63}$ Such a common dominant paradigm was achieved under German monetary hegemony: the governance of their anchor currency would henceforth be pooled, but according to benchmarks and disciplines that the German monetary authorities would primarily define. ${ }^{64}$ However, in the social field there is no such hegemonic definition of common goals; there is no social model which through normative discourse or through hegemonic position can present itself as THE benchmark. Therefore, the top-down definition of European benchmarks in the social field may be seen as an unnecessary imposition which puts further into doubt the legitimacy of European intervention. Given these substantial differences, benchmarking in social policy should be bottom-up, involving decentralised learning networks driven to a substantial extent by the policy actors in the individual countries. ${ }^{65}$

Second, employment and social policy issues (such as pension reform and social inclusion) often deal with redistributive questions that are traditionally legitimated on the basis of parliamentary representation. Attributing precisely these policy sectors to the OMC is problematic if the OMC procedure is characterised by lack of public and parliamentary debate. The EP is only marginally involved and the national parliaments and media are hardly aware of the existence of the OMC procedures.

In particular in relation to the EES, the framing of employment policy at European level, in a top-down technocratic manner - beyond the scope of broad parliamentary and political debate - is even more problematic if one takes into account the 'expanding nature' of the EES on the European social dimension. ${ }^{66}$ EC labour law is increasingly thought as a tool for European employment policy, and one can see 'a re-orientation from an approach to labour market regulation which had as its core a strong concept of employment protection and high labour standards, to an approach which prioritises employment creation, and minimises the role of social policy, since social policy is seen

\footnotetext{
62 I. Begg and J.Berghman, Introduction: EU social (exclusion) policy revisited?, in Journal of European Social Policy, Vol.12 (2002) No.3, p.193

63 D. Hodson and I. Maher, The Open Method as a New Mode of Governance: The Case of Soft Economic Policy Co-ordination, in Journal of Common Market Studies, Vol. 39 (2001) No.4, p.738. C. De la Porte, P. Pochet and G. Room, Social benchmarking, policy making and new governance in the EU, in Journal of European Social Policy (2001) Vol.11, No.4, p.294. Ibid, p.304.

66 N. Bruun, The European Employment Strategy and the 'Acquis Communitaire' of Labour Law, p.309.
} 
as potentially increasing the regulatory burden. ${ }^{67}$ This shift from 'social policy' to 'employment policy' will influence policy priorities at national (and sub-national) level. Although convergent trends may exist at national level, ${ }^{68}$ one can question the legitimacy of a European framework which - although not binding - has considerable influence in setting normative guides without a developed political debate.

Third, the OMC is a flexible process of which the objectives can continuously be adjusted - be it less or more demanding - without offering the same guarantee for ensuring minimum levels of protection as legislation can provide. With its mix of OMC procedures, for instance, the Lisbon Summit could please both the liberals with its economic reforms and the socialists with the safeguarding of the EU social model. Yet, already at the following Stockholm Summit this fragile balance was shaking under the pressure of those advocating to use the OMC strategy in favour of faster liberalisation and the speeding up of implementation of the internal market on the one hand, and those insisting upon the safeguarding of the European model via OMC and macro-economic coordination on the other hand. ${ }^{69}$ As a tool to help the European social model survive, the OMC may not provide the guarantees that legislation can.

Seen from this critical angle the OMC should be dubbed 'the Open Method of Centralisation': 'centralisation' since it leads to the definition at the central European level of policy choices that otherwise would be taken at lower levels; 'open', not in terms of participation of stakeholders or public scrutiny, ${ }^{70}$ but only in terms of flexible or 'unpredictable"71 - policy outcomes. Yet, the OMC has some potential to be 'decentralised'.

\section{Decentralising the OMC}

\subsection{From '(Output-)Open Method of Centralisation' to '(Input-)Open Method of Coordination'}

To turn the OMC from an '(Output-)Open Method of Centralisation' into an '(Input-) Open Method of Coordination', several (partially complementary) solutions may be

D. Ashiagbor, EMU and the Shift in the European Labour Law Agenda: From 'Social Policy' to 'Employment Policy', in: European Law Journal (2001), Vol.7, No.3, p.311.

See, for instance, the changes in collective bargaining in Germany from essentially a tool to improve working conditions to an instrument to save threatened jobs and create new ones; Achim Seifert, Employment Protection and Employment Promotion as Goals of Collective Bargaining in the Federal Republic of Germany, in: The International Journal of Comparative Labour Law and Industrial Relations (1999) Vol.15, No.4, p.343-364.

69 J. Goetschy, The European employment strategy from Amsterdam to Stockholm, p.407.

70 Some have noticed the irony of the term open method of coordination since it is perceived as being much more closed than the Community method. See K. Jacobsson and A. Vifell, Integration by deliberation?, p.23.

Namely, it is difficult to predict where the continuing adjustments of benchmarks will lead us. 
considered:

First, one can question to what extent OMC processes need to define detailed objectives at European level. In the fields of social inclusion and pension reform the OMCs do not provide detailed objectives relating to the content of national social policies. This more heterarchical process aims at creating opportunities for learning, innovation and experimentation at national, regional and local levels without defining at the central level the objectives with any degree of specificity. The question - the answer to which is beyond the scope of this paper - is to what extent one needs the definition of common European objectives and policy choices - under the form or disguise of benchmarks - to reconcile the realisation of the single market and EMU with satisfying employment rates. If there is no clear added value of common targets and policy choices, the subsidiarity principle would favour an OMC process that aims primarily at horizontal mutual learning. ${ }^{72}$

Second, in reply to the open-ended character of OMC processes, one may think about a role for constitutional values which are less malleable than constantly revisable (up or down) policy standards. ${ }^{73}$ The Charter of Fundamental Rights of the EU for instance could provide a set of substantive (even if largely abstract) norms to guard against a tendency to 'race downwards' or fall below an acceptable threshold. In the same sense it has been suggested that the Treaty should include a statement of fundamental principles of social protection, which could function as threshold for OMC processes. ${ }^{74}$ However, the European Convention preparing the new IGC has not taken this suggestion on board.

Third, in reply to the technocratic character of the 'centralising OMC' one may opt for a stronger parliamentary involvement; at national level by parliamentary debate on the NAPs and at European level by an increased role for the EP. Thus it has been suggested that, in addition to the consultation of the EP taking place according to the current Treaty previsions, one could include representatives from the EP in the Employment Committee. ${ }^{75}$ Yet, others question whether an increased role for the EP in OMC procedures would really be the right solution to democratise the OMC. If the European level is only concerned with coordination at a cognitive level, through providing frames for analysis and common objectives, whereas the real policy decisions are supposed to be made at national level; it should be above all at that level that

72 In this sense, P. Syrpis, Legitimising European Governance, p.52; and C. De la Porte, P. Pochet and

G. Room, Social benchmarking, policy making and new governance in the EU, p.304.

73 G. de Búrca, The Constitutional Challenge of New Governance in the European Union, in European Law Review (forthcoming).

74 According to F. Vandenbroucke, Belgian Minister for Social Affairs and Pensions, Article 3 al.2 TEC Treaty should be completed as follows: 'in all activities refered to in this Article, the Community shall aim to eliminate inequalities and to promote equality between men and women and shall take into account social protection requirements, in particular with a view to promoting accessible and financially sustainable social protection of high quality organised on the basis of solidarity.' F. Vandenbroucke, The EU and Social Protection: What should the European Convention propose?, Max Planck Köln, MPIFG Working Paper 02/6, June 2002, p.20, at http://www.mpi-fg-koeln.mpg.de/pu/workpapers_en.html

75 M. Tsakatika, The Open Method of Co-ordination in the European Convention : Efficient and Legitimate?, paper presented at the ECPR Joint Sessions Edinburgh March-April 2003, p.13. 
democratic debate should be guaranteed. ${ }^{76}$ Yet, one could counter argue that this assumption seems currently not to be confirmed by reality. This brings us to the last suggestion.

Fourth, even if one would not define detailed objectives at European level; and even if one would use fundamental rights as a threshold; and even if parliamentary involvement would be strengthened, the OMC can only be a non-centralising benchmarking exercise if decentralised participation is strengthened. Only by enforcing the participation of social partners, civil society organisations and sub-national authorities in both the implementation of the EES and in its annual assessment, one could gradually ensure the redrafting of European guidelines based on locally gathered experience. An important way to strengthen the 'fully decentralised approach' is to encourage synergies between employment policy on the one hand and territorial politics on the other.

\subsection{The synergy of employment policy and territorial politics}

Approaches to territorial politics have changed over the last decades; from the centralised regional policies, based on top-down spatial planning aimed at diverting investment to areas of need, to more locally-based approaches which should encourage endogenous economic development and policy learning in regional networks. While attracting external investment remains important, the 'philosophy of endogenous economic development' stresses the importance of local human capital, cultivating local firms and local resources, and creating economic synergies among local actors. Less emphasis is placed on physical infrastructure and more on human resources development and technology transfer through networks and linkages among firms and between them, universities, research centres and governments. ${ }^{77}$

In parallel to these developments, employment policies have been changing over time: from employment policies set in the context of central neo-corporatist macroeconomic concertation (and wage bargaining) to more decentralised employment policies, taking into account multi-level industrial relations systems and acknowledging the 'territorial dimension' of employment questions. Rising unemployment under conditions of increased international competition has changed the nature of collective bargaining: initially a tool which - once the macro-economic and wage bargain was set - could primarily aim at improving working conditions, collective bargaining has become a trade-off between saving threatened jobs and accepting 'flexibilization of working conditions'. ${ }^{78}$ Contrary to some predictions of the $1980 \mathrm{~s},{ }^{79}$ this growing

76 R. Dehousse, Du bon usage de la méthode ouverte de coordination, (forthcoming). To date the OMC does not include any mandatory provisions for the Member States to involve their national parliament.

M. Keating, Territorial Politics and the New Regionalism, in P. Heywood, E. Jones and M. Rhodes (eds), Developments in West European Politics, Houndmills, Palgrave, 2002, p.201; A. Benz and D.

Fürst, Policy Learning in Regional Networks, in: European Urban and Regional Studies Vol.9 (2002) No.1, p.21; C. Ansell, The Networked Polity: Regional Development in Western Europe, European University Institute Conference Paper EUR/37, 2000.

78 J. Bélanger and C. Thuderoz, La recodification de la relation d'emploi, Revue Française de Sociologie 39 (1998) 3, p.469. A. Seifert, Employment Protection and Employment Promotion as 
international competition has not meant the end of national concertation. ${ }^{80}$ However, while national concertation has partially been revived during the 1990s, this has been combined with decentralised negotiation at sectoral and firm-level. ${ }^{81}$ National bargaining would only provide the framework whereas sectoral and enterprise level negotiations can ensure the flexibility needed under conditions of increased international competition. ${ }^{82}$ It has been argued that EMU would further increase decentralisation of collective bargaining combined with a search for social concertation (such as 'job pacts') at national level. ${ }^{83}$

In addition, one has noted a certain 'territorialisation' of employment policies. ${ }^{84}$ There is an increasing awareness that tackling unemployment is not just a question of centralised macro-economic policies, but should take into account both the particular problems and the potential of local conditions. In many member states this awareness has led to the devolution to regional and local authorities of competencies to combat unemployment. Largely in line with the philosophy of endogenous economic development this has contributed to tackling unemployment at sub-national level by such instruments as 'territorial pacts', linking local actors to combat unemployment in the specific local context.

Awareness of the territorial dimension of employment has inspired the EES as early as in the 1993 White Paper on Growth, Competitiveness, and Employment, which asserts that unemployment is a problem of micro-economic causes and local dimensions. Large investment in continental infrastructure such as the 'trans-European

Goals of Collective Bargaining in the Federal Republic of Germany, in : The International Journal of Comparative Labour Law and Industrial Relations 15 (1999) 4, p.343.

P. Kurzer, Unemployment in open economies: the impact of trade, finance and European integration, in: Comparative Political Studies 24 (1991) 1, p.3.

For the remaining role of national concertation (even in the context of increased international competition during the 1990s), see B. Ebbinghaus and A. Hassel, Sriking deals: concertation in the reform of continental European welfare states, in: Journal of European Public Policy (2000) Vol.7, No.1, pp.44-62; and G. Fajertag and P. Pochet (eds), Social Pacts in Europe, Brussels, European Trade Union Institute, 1997.

81 O. Molina and M. Rhodes, Corporatism: The Past, Present, and Future of a Concept, in: Annual Review of Political Sciences 5 (2002), p.305-331.

82 F. Traxler, Farewell to Labour Market Associations? Organized versus Disorganized Decentralization as a Map for Industrial Relations', in: C. Crouch and F. Traxler (eds), Organized Industrial Relations in Europe: What Future?, Aldershot, Avebury, p.23-44; and E. Léonard, Industrial Relations and the Regulation of Employment in Europe, in: European Journal of Industrial Relations Vol.7 (2001) No.1, p.36.

M. Biagi, The European Monetary Union and Industrial Relations, in : The International Journal of Comparative Labour Law and Industrial Relations, Vol.16 (2000) No.1, p.39-45.

See, for instance, for Italy : J.L. Laville, Le iniziative locali in Europa: un bilancio economico e sociale, Torino, 1999; M. Ferrera and E. Gualmini, Rescue from Without? Italian Social Policies 1970-1999 and the Challenges of Internationalization, European University Institute, Working Paper EUF 99/13. For France: D. Béhar, P. Estèbe and R. Epstein, Les détours de l'égalité - Remarques sur la territorialisation des politiques sociales en France, in Revue française des affaires sociales, Vol.52 (1998) No.4, p.81-94 ; and J. Godard, Towards a Local Governance of Employment? Institutional 'changes' and 'new' partnerships in French (un)employment policies, paper presented at the ECPR Joint Sessions Edinburgh March April 2003. For Spain: R. Gallego, R. Gomà and J.Subirats, Welfare state and territorial politics: the emergence of regional welfare regimes in Spain, paper presented at the ECPR Joint Sessions Edinburgh March April 2003. 
networks', and macro-economic policies can - at best - do little more than facilitate local efforts. Inspired by this approach, the Commission published in 1995 a Communication on 'A European strategy for encouraging local development and employment initiative', ${ }^{85}$ and started to launch 'Territorial Employment Pacts' as pilot projects since 1997. In a comparable way, the development of the OMC procedure had the aim to build an EES not on the basis of a strong European centralised macroeconomic and financial support policy but as a mere co-ordination of decentralised policies.

However, the development of a territorialized EES faces several problems:

First, there is still a lack of synergy between the OMC procedure on the one hand, and Community 'territorial policies' on the other hand. As analysed above, the OMC, despite its rhetoric on decentralisation, provides above all an institutionalised structure that places the member states and their governments at the core of employment policy. Moreover, also the content of the OMC guidelines gives particular capacity for initiative to national governments: the primary mechanisms pointed out in the EES appear to be incentives linked to tax, social security and 'modernizing work organization'- which all remain firmly in the grip of the national governments. ${ }^{86}$

On the other hand, the Community has at its disposal several instruments of 'territorial politics' to address the local dimension of unemployment. Community initiatives and pilot projects are used to encourage Territorial Employment Pacts, and more recently, Local Action Plans. ${ }^{87}$ Moreover, the Regulations governing the Structural Funds for the 2000-2006 period state that the Funds should play a particular role in favour of local economic development, by promoting, among others Territorial Employment Pacts. ${ }^{88}$ In fact, with the European Social Fund the Community for decades has disposed of a structural policy instrument to deal with unemployment. The task is to streamline Community Initiatives, pilot projects and ESF interventions with the OMC procedure. To date they are far too much two different worlds; the Structural Funds and the OMC have different policy cycles, and are handled with by different administrations at both European and (sub-)national level. ${ }^{89}$

Second, a territorialized EES obviously does not only result from a streamlining of employment policy and territorial politics at EU level but depends on the institutional framework it can build on at sub-national level within the member states. ${ }^{90}$ A symbolic

COM (95) 273, 13 June 1995.

See also E. Léonard, Industrial Relations and the Regulation of Employment in Europe, in: European Journal of Industrial Relations Vol.7 (2001) No.1, p.34.

Commission Communication on Strengthening the local dimension of the European Employment Strategy, COM (2001)629 final, 6/11/2001.

Regulation EC 1784/1999 of 12 July 1999 on the European Social Fund, OJ 13.8.1999, L 213/6, Article 2.2.(a).

I. Hartwig, Incremental Synergies or Growing Fragmentation between the Luxembourg process and EU Structural Funds?, paper presented at ECPR First Pan-European Conference on European Integration, Bordeaux 26-28 September 2002.

According to Benz and Fürst 'optimal institutional arrangements' for regional development include the existance of a regional council, boundary-spanning institutions such as Chambers of Commerce, an independent agency endowed with the power to initiate policies, and a central government which abstains from strict control and instead sets an instutional framework and standards for interregional 
discourse on the territorialisation of public policies without structural modifications in administrative structures and routines - as shown, for instance, in France - will not suffice. $^{91}$

Third, even boosting 'the third level', i.e. providing the regional (and local) public authorities with the necessary powers in employment matters - and adjusting administrative practices to that - will not suffice to develop a successful 'territorialized EES'. Tackling employment issues within their territorial context also requires strong relations with the socio-economic players within that territory. However, 'traditional' industrial relations systems haven't (yet) adjusted to such a territorialisation of employment and economic policies. Trade unions, for instance, are strongly organised through a chain of institutional settings including the national, sectoral and enterprise level. However, they lack well-established structures at regional and local level, and it has been noted, also in relation to the EES, that they have not been strong supporters of local initiatives. ${ }^{92}$ Big companies, on the other hand, keep their traditional distrust as regards political claims to intervene in the economic field, and focus on 'decentralisation' in terms of greater autonomy to negotiate at company level rather than linking their fate to 'decentralisation' in terms of boosting the position of a particular region in collaboration with sub-national public authorities. SMEs fit best with the idea of territorialized policy-making, but they are difficult to collectively mobilize in the long term. ${ }^{93}$

Fourth, as the different interests of socio-economic players illustrate, there is a more profound 'ideological tension' within the idea of territorializing employment policy. Although simplified, one could argue that as long as employment policy was part of the national neo-corporatist bargain, it could build on 'national interest' bringing together management and labour (and to a certain extent even national big industries) encompassing structures based on class and sector solidarities. In the globalised, postKeynesian and post-Fordist society this is ever less the case. The regional reply - which inspires territorialized policy-making - suggests that in this new context the locality, from being a mere space in which market forces operate, becomes a key element in production itself. Regions, not just firms and nation states, compete for investment, markets and technology. However, this has radical implications for politics since it postulates a common regional interest in competition overriding other solidarities based on national identity, class or sector. ${ }^{94}$

competition; see A. Benz and D. Fürst, Policy Learning in Regional Networks, p.31.

91 J. Godard, Towards a Local Governance of Employment?, p.6. For a more optimistic evaluation of the territorialisation of public policies even in the case of administrative and artificial regions, see Marco Brunazzo in this volume.

92 Commission, First Report on Local Development and Employment Initiatives: Lessons For Territorial and Local Employment Pacts (1997). Also S. Sciarra, Integration Through Coordination: The Employment Title in the Amsterdam Treaty, in: The Columbia Journal of European Law (2000) Vol.6, No.2, p.214. 


\section{Conclusion}

On 22 July 2003, the Council adopted the new employment guidelines. ${ }^{95}$ The guidelines are strongly reduced in number and are no longer structured in four pillars: they define three overarching objectives - namely, full employment, improving quality and productivity at work, and strengthening social cohesion and inclusion - and include 10 specific guidelines. The document also contains a final section dealing with 'good governance and partnership in the implementation of the employment guidelines'.

It is phrased in general terms, not adding substantially to the rhetoric of the previous guidelines; although, the section starts more explicitly with a reference to the need to include the regional and local level to ensure the effective implementation of the Employment guidelines.

To decentralise the EES beyond the rhetoric of the policy documents, two elements should in particular be taken into account:

First, the Treaty provisions defining the institutional framework for the EES should be revised in such a way that the OMC takes into account the multi-level nature of European governance, in particular regarding the peer review process but also regarding the implementation of employment policy. However, whereas there are de facto signs of the development of an institutional framework for a decentralised EES, such as the Commission's proposal (following the Laeken Summit) to set up a tripartite concertation body for growth and employment which would involve each year the social partners on the eve of the Spring European Council, the constitutional debate in the European Convention has shown little interest in redefining the OMC's institutional framework within the Treaty. The final draft Constitution proposed by the Convention (CONV 820/03) does not include a general procedure on OMC, and the provisions on the guidelines procedure of the EES have remained untouched.

Second, while the position of the social partners within the EES has gradually been improved through the Guidelines of the last years, and much now also depend on how effective they will be themselves in developing 'their process within the process', much more needs to be done to strengthen the role of regional and local authorities within the EES. Looking for synergies between employment policy and territorial politics would strengthen such a decentralised involvement. The new employment guidelines appear aware of this need. Among the (limited number) of guidelines, one is entirely dedicated to 'addressing regional employment disparities'. 'The potential for job creation at the local level, including the social economy, should be supported and partnerships between all relevant actors should be encouraged'. Moreover, the guideline stresses that 'the potential of the Cohesion and Structural Funds and the European Investment Bank should be fully exploited'. However, there are no indications on how synergies between structural funds and the EES should be created, nor on how partnerships should be organised at local level. To date, the approach remains largely a top-down suggestion to include regional and local actors ('in accordance with national traditions') in the implementation of guidelines. It does neither realise a real territorialisation of employment policies nor provide the framework for a decentralised involvement that 
would feedback into the OMC's review process and help to reformulate future employment priorities and strategies. 